\title{
Hvordan responderer konfirmanter på kirkens påskefortelling?
}

Av Caroline Vesterberg

I 2017 ble 35519 ungdommer konfirmert $i$ den norske kirke1. Hva vet vi om hvordan disse erfarer undervisningen de mottar? Hva er de opptatt av, hva husker de og hvordan tenker de? Hva slags forhold er det mellom gjennomført undervisning og konfirmantenes respons, og bør deres respons få følger for undervisningens innhold og metodikk?

Av CARoline Vesterberg, kateket i Haslum menighet. E-post: cv888@kirken.no

Jeg har forsket på min egen konfirmantundervisning ut fra en analyse av konfirmantenes skriftlige og muntlige respons ${ }^{2}$. Målet med undervisningen var at konfirmantene skulle oppleve påskefortellingen i en større sammenheng og få forklart de fire viktigste dagene med en tematikk og ordbruk som har forankringspunkter i deres egen hverdag. For at de skulle huske undervisningen i etterkant, brukte vi handlinger og ritualer som tydeliggjorte hver påskedags egenart. Undervisningens varighet var 90 minutter og foregikk sammen med en prest. Jeg forsket på egen undervisning ut fra et teoretisk rammeverk om læreplaner og deres fem ansikter (Goodlad, 1979) med vekt på gjennomført og erfart læreplan. I det følgende vil jeg si noe kort om hvordan jeg har arbeidet, om læreplan og kontekstuell teologi, før jeg presenterer og analyserer konfirmantenes respons.

\section{Prosjektets forløp}

I figuren nedenfor angir jeg en skisse for hvordan jeg har gått frem med den kvalitative studien av konfirmasjonsundervisningen om påskens fire viktigste dager. (Se fig. 1 på neste side.)

\section{LEREPLANER}

Goodlad (1979. s. 60-64) hevder at læreplanen har fem ansikter (på norsk angis disse hos Gundem (1990, 1993), jamfør også Imsen - 2016 s. 278-280). Læreplanen deles dermed inn i den ideologiske, den formelle, den oppfattede, den gjennomførte og den erfarte læreplan. Den ideologiske læreplanen er de

1 ssb.no lest 28. juni 2018

2 Artikkelen bygger på min masteravhandling i kirkelig undervisning fra det teologiske menighetsfakultetet i 2017: «Hvordan responderer konfirmanter på kirkens påskefortelling? En kvalitativ studie av en konfirmasjonsundervisning med vekt på hvilke følger konfirmantenes respons kan ha for undervisningens innhold og metoder.» 
Konfirmasjonsundervisning om påske:

3 konfirmantgrupper med ca

20 deltagere i hver gruppe.

Hver gruppe hadde $90 \mathrm{~min}$

undervisning om påskens fire

dager. Denne undervisningen

fulgte samme mal.
Konfirmantenes aktivitet

på undervisningen:

1. Lesespørsmål

2. Bønnelapper

3. Deltakelse i ritualer

Utdeling av hjemmeoppgave
Gjennomgang av hjemme-

oppgaver:

Utvalg av informanter ut fra

forskningsspørsmålene og representativitet i kjønn og bildevalg

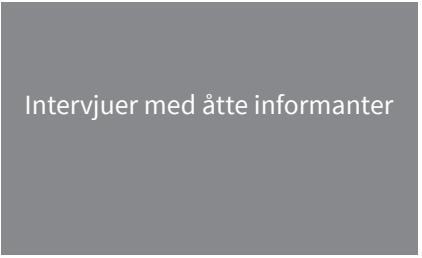

Materialetablering:

1. Deltakende observasjon

2. Multimodal analyse hvor tekst-

formidling og tekstforståelse står

sentralt

3. Tekstanalyse: bak, i og foran

teksten

[Fig. 1]

tankene og idealene som kan prege en læreplans utforming og som ikke finnes i en ren, konkret form. Den formelle læreplanen er et konkret dokument som er offentlig vedtatt. For konfirmantundervisningens vedkommende er den formelle læreplanen Gud gir - vi deler (Kirkerådet, 2010). Den oppfattede læreplanen handler om hvordan ulike aktører tolker den formelle læreplanen forskjellig. I mitt case har jeg vært opptatt av det siste ansiktet, den erfarte læreplanen, hvor konfirmantenes respons er plassert. Denne dreier seg om elevenes erfaringer av hva som foregår i klasserommet eller undervisningslokalet. Hva oppfatter og lærer de? Hva får de med seg av det som er målet for undervisningen? I og med at jeg har forsket på egen undervisning, ble det også relevant å se på den gjennomførte læreplanen - den faktiske undervisningen - og forholdet mellom denne og den erfarte læreplanen.

\section{Kirkens Lereplan: Gud gir - Vi Deler}

Før jeg går inn på gjennomført og erfart læreplan i mitt konkrete case, vil jeg kort redegjøre for det ideologiske og formelle «ansiktet». Plan for trosopplæring: Gud gir - vi deler (Kirkerådet, 2010) har ni kapitler. I denne artikkelen vil jeg vektlegge de kapitlene som er relevante for å gi et inntrykk av de hovedsakelige retningslinjene i den kirkelige læreplanen. Derfor skildrer jeg kapittel én om livslang læring; kapittel tre som handler om trosopplæringens innhold, og til slutt kapittel fem, hvor det gis retningslinjer for konfirmasjonstiden.

\section{Ideologisk læreplan}

Den norske kirkes trosopplæringsplan har sitt ideologiske utgangspunkt i Jesu oppdrag om å døpe til Faderens, Sønnens og Den hellige ånds navn (Matt 28, 
18-20). Dåpen skjer en gang, men den døpte skal samtidig læres opp til å leve og vokse i sitt forhold til den treenige Gud (Kirkerådet 1998, s. 7).

\section{Formell læreplan}

Konfirmasjonsundervisningen er en del av menighetens trosopplæring. I Plan for trosopplæring (Kirkerådet, 2010) har disse rammene et eget avsnitt hvor det er angitt noen premisser for konfirmasjonstiden:

- Konfirmasjonen gjennomføres normalt det året konfirmantene fyller 15 år.

- Konfirmasjonstiden bør gjennomføres over et tidsrom på åtte måneder med et anslått omfang på 60 timer.

- Da det er viktig at det er jevnlig kontakt mellom konfirmant og menighet, kan ikke leir overskride 50 prosent av det totale undervisningsomfanget.

Konfirmantene skal, i løpet av konfirmasjonstiden, arbeide med de tre hovedtemaene i trosopplæringen: Livstolkning og livsmestring, kirkens tro og tradisjon og kristen tro i praksis.

Livstolkning og livsmestring innebærer å forstå seg selv og andre, i lys av relasjonen med den Treenige Gud. Dette skal bidra til livsmestring i gode og dårlige tider. I kirkens tro og tradisjon skal trosopplæringen formidle den kristne troen, slik den kommer til uttrykk i Bibelen, gudstjenestene og bekjennelsesskriftene. Her inngår budene, Vår Far og trosbekjennelsen.

Det siste hovedtemaet, kristen tro i praksis, omfatter å delta på gudstjeneste, bønn, lovsang, og lesing av bibelen. Den kristne troen leves ut gjennom å være medmenneske i familie og samfunn, gjennom hver enkelt sine forutsetninger (Kirkerådet, 2010, s. 14).

Planen for trosopplæring gir et inntrykk av at konfirmasjonstiden skal gi noe fordypning i kristendommen, heller enn å være repeterende og oppsummerende. Den angir også et minimum av kunnskapsinnhold, som gjelder trosbekjennelsen, de ti bud og Vår far. Konfirmantene skal ha deltatt på gudstjenester i en grad at de blir fortrolige med gudstjenesten og sakramentene og kan kjenne Bibelens fortelling, sett i lys av sin egen og fellesskapets fortelling (Kirkerådet 2010, s. 24). Det står ikke noe eksplisitt om bruk av påskefortellingen i konfirmasjonstiden. Derimot angis den som en kjernetekst i en fornyet trosopplæring hvor den kan utvides til gjentakelse og fordypning i det sentrale for de eldre aldersgruppene (Kirkerådet, 2010, s. 46).

Jeg tolker kirkens læreplan som fellesskapsorientert. Da konfirmanten anses være en deltager i kirkens fellesskap, med et mål om fortrolighet med gudstjenestefeiring, sakramenter og bønn, blir denne en annen type konfirmasjonsundervisningenn den jeg har forsket på som «ren konfirmantundervisning». For å lære om kirkens tro i praksis skal konfirmanten delta i gudstjenester, 
sakramenter og forstå bibelen i lys av fellesskapets og sin egen livsfortelling. Den kirkelige læreplanen har fellesskapet med den treenige Gud i dåpen som norm. Å være døpt innebærer å vokse i troen. Aspektene livstolkning og livsmestring, kirkens tro og tradisjon og kristen tro i praksis, er vesentlige deler i en slik vekstbasert trosopplæring.

\section{UNDERVISNINGENS TEOLOGISKE RAMME}

Presten som hadde undervisningen sammen med meg, studerte frigjøringsteologi i en sørafrikansk kontekst. Da vi planla påskeundervisningen, $\emptyset$ nsket vi at denne skulle ha en basis i kontekstuell teologi, for å gjøre undervisningen livsnær for konfirmantene.

Kontekstuell teologi må nyformes i lys av den aktuelle konteksten som bibelteksten skal brukes innenfor. Det innebærer å legge til rette for bruk av bibeltekster slik at de kan bidra til å belyse menneskers liv der de blir lest. Ifølge den kontekstuelle teologien er det her den ekte teologien blir til, da leseren tar imot det som er gitt og gjør det til sitt eget. I dette tilfelle er konfirmantene lesere av påsketekstene i Matteusevangeliet, hvor de tilegner seg tekstene på sin måte, i sin kontekst. Kontekst innebærer dermed en gruppes eller en individs liv, liv som innebærer suksess, feiltakelser, relasjoner osv, faktorer som tillater eller forhindrer Gudserfaring i livet (Bevans, 2002, s. 5). I Models of contextual theology (Bevans, 2002) skisseres seks forskjellige metoder for kontekstuell teologi. En av disse ble spesielt relevant i vår sammenheng: Praksismodellen. Denne modellen har sitt utgangspunkt i dagens virkelighet og framtidens muligheter (Bevans, 2002, s. 72). Her henger frigjøring og forandring sammen i kallet til å være Guds barn. Når handlingen kommer først og så refleksjonen, kan praksismodellen bli relevant for en helt spesifikk kontekst (Bevans, 2002, s. 73-74). I praksismodellen er Guds åpenbaring sentral. Her forstås den som Guds nærvær i historien, $\mathrm{i}$ hverdagslivet, i sosio- $\emptyset$ konomiske strukturer, $i$ undertrykkende situasjoner og $\mathrm{i}$ fattige og marginalisertes erfaringer. I nåtiden inviterer Gud kvinner og menn til å samarbeide om rettferdighet og frigjøring (Bevans, 2002, s. 75). Denne konfirmasjonsundervisningen tolket langfredags- og første påskedagsfortellingen ut fra rettferdighets- og frigjøringsterminologi.

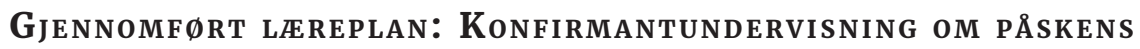 FIRE VIKTIGSTE DAGER}

I undervisningen deltok 65 konfirmanter, fordelt på tre grupper. Da jeg og presten planla påskeundervisningen, hadde vi følgende målformuleringer:

- Konfirmantene skal kjenne innholdet i de fire viktigste påskedagene og hva som skjedde i påskeuken 
- Konfirmantene skal få en erfaring av hva som skjedde, gjennom fortelling, ritualer, taktile, auditive og visuelle hjelpemidler

- Undervisningen skal være livsnær. Konfirmantene skal kunne identifisere seg med påskefortellingene gjennom forklaring av frelse som frihet fra slaveri i vår tid, sette ord på det som ødelegger og er urettferdig, og skildre Jesus som venn og som ensom

For å oppnå disse målformuleringene fulgte hver gruppeundervisning en bestemt inndeling:

Trinn 1: Muntlig fortelling fra Peters påske (Skeie, 1997)

Trinn 2: Input teori

Trinn 3: Opplevelse

Trinn 4: Bibellesning med lesespørsmål i gruppe

Ved å følge denne malen for undervisningen ønsket vi å bryte med den tradisjonelle undervisningsformen hvor konfirmantene sitter på stoler og lytter, og de ansatte bruker frontal, verbal formidling.

Peters påske er en bok som beskriver påskedagene ut fra disippelen Peters perspektiv. Vi valgte ut deler av boken som hørte til hver aktuell påskedag, som vi fortalte utenat til konfirmantene. Til første påskedag ble det fortalt ut fra Maria Magdalenas perspektiv, en fortelling som jeg hadde skrevet.

Jeg redegjør kort for de fire dagenes input teori og opplevelse, altså trinn 2 og 3. Trinn 4 blir beskrevet under erfart læreplan. På palmesøndag dreide input teorien seg om profeten Sakarja, messiasforventninger og Jesus som annerledeskongen, som ikke skulle starte krig med romerne, men som oppfordret til omvendelse og fred. Det ble fortalt om hele påskeuken som «den stille uka», og derfor var opplevelsen et stille minutt.

På undervisningen knyttet til skjærtorsdag introduserte vi opplevelsen håndvask. Konfirmantene kom frem to og to. Kateketen helte varmt, velduftende vann over hendene deres, og presten tørket dem med et håndkle. Nattverdens jødiske bakgrunn og utferden fra Egypt ble forklart under input teori i tillegg til de fire evangelistenes forskjellige versjoner av skjærtorsdag.

På langfredagsundervisningen gikk konfirmantene inn i et mindre rom, hvor stolene var plassert i en halvsirkel rundt et bord med en svart fløyelsduk. På bordet lå et trekors og en tornekrone, og fem røde roser som skulle symbolisere Jesu fem sår, sto i en vase. Etter input teorien om hvordan langfredagsgudstjenesten i den lokale kirke feires, med urettferdighet og Gud som vet hva lidelse er, som bakteppe, fikk konfirmantene instruksjoner om å skrive bønnelapper. Disse bønnelappene skulle være anonyme og handle om noe de syntes var urettferdig, vondt eller vanskelig. Da de var ferdige, skulle de feste bønnelappene på trekorset. 
Ved siste delen av undervisningen gikk konfirmantene tilbake til det første rommet. Det var nå gjort om, og et alter med hvit duk, mange tente lys og påskeliljer, sto på scenen, foran konfirmantenes sitteplasser. På gulvet lå et kors av to striper av aluminiumsfolie og telys i en bolle ved siden av. Jesu oppstandelse ble forklart ut fra frihet fra slaveri og hvordan vi som mennesker kan være slaver under frykten, kravene og synden. Vi er mer eller mindre redde for å ikke være gode nok, samfunnet og kulturen vi er en del av, sier hvor flinke og fine vi skal være. Så gjør vi dumme ting grunnet det onde i oss og rundt oss. Dette kan Jesus befri oss fra, gjennom at vi kan vite at vi er skapt og elsket av Gud som gir oss tilgivelse for det vi har gjort galt. Opplevelsen var å tenne lys, mens vi hørte på musikk. Undervisningen ble avsluttet ved at vi ba Vår Far og at presten lyste velsignelsen.

\section{Erfart lereplan: Konfirmantenes Respons P§̊ PÅSKEUNDERVISNINGEN}

Metodene som ble brukt for å kartlegge konfirmantenes respons var deltakende observasjon, de skriftlige svarene på lesespørsmålene, bønnelapper, konfirmantenes hjemmeoppgaver og intervjuer med åtte informanter. Den deltakende observasjonen ble foretatt av den som ikke ledet undervisningen. Det vil si at presten observerte min undervisning og noterte underveis, og motsatt. Datamaterialet fra hjemmeoppgavene og intervjuene ble tillagt mest vekt $\mathrm{i}$ masteravhandlingen, og følgelig også i denne artikkelen. Jeg deler derfor inn responsen i to deler: Responsen på selve undervisningen og responsen etter undervisningen. I den første delen gjør jeg rede for de store trekkene i observasjonen, lesesp $\varnothing$ rsmålene og bønnelappene. I den andre delen presenterer jeg responsen fra hjemmeoppgavene og intervjuene.

\section{RESPONS PÅ UNDERVISNINGEN \\ Deltakende observasjon}

Det er viktig å si at vi opplevde at alle tre gruppene oppførte seg ganske likt, både når det gjaldt arbeidsro og reaksjoner på undervisningen. De satte seg kjønnsdelt. Guttene på den ene siden av salen, og jentene på den andre. Jentene brukte generelt mer tid på å svare på lesespørsmål, skrive bønnelapper og tenne lys. Da vi bar inn vann, såpe og håndklær til skjærtorsdagen, reagerte konfirmantene med fnising, mummel og oppspilthet. Vi opplevde gruppene som oppmerksomme ved den muntlige fortellingen, litt tøysete ved lesespørsmålene, men totalt sett: Enkle å få med på det vi hadde planlagt av undervisning.

\section{Trinn 4: Lesespørsmål i gruppe}

Etter fortelling, opplevelse og input teori, satte konfirmantene seg i mindre 
grupper og arbeidet med lesespørsmål. Det foregikk slik at de fikk utdelt lapper med bibelteksten på, og spørsmål som hørte til teksten. Først leste de bibelteksten, og så svarte de på spørsmålene. Spørsmålene til de tre dagene (på langfredag fikk de skrive bønnelapper i stedet for) var av varierende kvalitet. Jeg oppdaget i etterkant at spørsmålene ikke samsvarte med skjærtorsdagens tekst. Derfor fikk jeg ikke svarene jeg hadde ønsket. Jeg har valgt ut noen svar på lesespørsmålene hver dag og avslutter med en kort analyse.

\section{Palmesøndag (Matteus 21,1-11)}

Hvis Jesus hadde blitt født og vokst opp i dag: Hvem hadde han vanket med? Han hadde prøvd å hjelpe de som trenger det mest. Han hadde nok hatt noen som fulgte han, som folk som liker idéene hans. Kanskje de som ikke er så veldig rike eller har det bra, som tiggere og fattige.

Han hadde sikkert vanket med folk som trengte hans hjelp, for eksempel flyktninger og tiggere.

Han hadde sikkert meldt seg inn i hjelpeorganisasjoner som Kirkens Nødhjelp.

Hvis Jesus hadde blitt født og vokst opp i dag hadde han hengt med Siv.

Vi tror han hadde vanket med Erna Solberg.

Han hadde vanket med de barmhjertige. Ikke muslimer.

Hvordan hadde du møtt ham?

Vi hadde synes at Jesus som Guds sønn var merkelig, og tenkt at han var litt gal.

Vi hadde vart vennlige.

Vi hadde tenkt han så vis ut og at han var rar. Vi tror vi hadde ledd av han.

På første spørsmålet svarer konfirmantene at Jesus hadde vært sammen med de marginaliserte og fattige i samfunnet. I andre sitater gis han stor grad av innflytelse, da de svarer at han hadde vært sammen med både Erna Solberg og Siv Jensen.

Ved sammenligning av bibelteksten og konfirmantenes lesing av den, er det tydelige tendenser på at konfirmantene hadde møtt Jesus med skepsis og redsel, i stedet for med glede.

\section{Skjærtorsdag (Matteus 26,26-46)}

Hva vil det si å være god venn ut fra teksten du leser?

Man kan dele, ikke si at du er bedre enn dem, være tro mot dem og ikke forråde venner.

Vare troverdig.

$\AA$ vare en god venn vil si å vœre lojal og snill og god.

Den utvalgte bibelteksten samsvarte som tidligere nevnt, ikke med spørsmålene. 
Derfor har alle svarene et allment preg. Kanskje hadde svarene vært annerledes om teksten hadde vært en annen, kanskje ikke. Det kan en bare spekulere i.

Første påskedag (Matteus 28,1-10)

Er det noe som du synes er vanskelig i teksten?

Vi synes det er vanskelig å tro på at dette virkelig har skjedd.

At det er to Mariar.

Vanskelig å tro at engelen dyttet vekk steinen

Vanskelig språk

At han står opp, men det hadde vart kult.

Mange av svarene tyder på at språket i teksten er fremmedgjørende, og at de derfor verken forstår det engelen eller Jesus sier. Englenes funksjon og virkning i teksten er vanskelig å forstå. Spesielt det faktum at de skremmer folk, selv om de kommer med et godt budskap.

\section{OPPSUMMERING LESESPøRSMÅL}

Vi ønsket at konfirmantene skulle sitte i en gruppe når de besvarte lesespørsmålene. Grunnen til det var at spørsmålene kunne fremme dialog om teksten og at konfirmantene kunne samarbeide om svarene. Det jeg så etterpå var at spørsmålene som ble stilt i jeg-form, ble besvart i vi- form, og det virker som at det var en gruppejustis som preget svarene. Flere svar harselerte med bibelteksten. Samtidig er det viktig å ta deres undring og innspill på alvor, til tross for den tøysete undertonen i flere av svarene.

\section{Langfredag \\ Bønnelapper}

Etter fortellingen og input teori på langfredagsundervisningen, skulle konfirmantene skrive lapper om det de syntes var vondt, vanskelig eller urettferdig og feste på et trekors som lå midt i halvsirkelen av stoler, hvor de var plassert $^{3}$. Konfirmantene fikk beskjed om at lappene skulle leveres uten navn og at vi skulle lese dem etterpå og be for innholdet på lappene. Det kan ha medført noe selvsensur på innhold hos konfirmantene ut fra valgt innhold. 66 lapper ble skrevet. Av dem anså jeg fem lapper som tull, og en lapp var blank. De resterende delte jeg ut fra innhold i tre kategorier: 1. Verden 2. Familien og 3. Meg selv.

1 I kategorien «verden» inngikk krig, sult, klimaproblematikk, terror, fordeling av goder, diskriminering og flyktningekrisen. Flest lapper ble skrevet her: 42 stykker totalt.

3 Konfirmantene fikk beskjed om å levere anonyme lapper. Informasjon om bruk av deres respons på konfirmantundervisningen ble informert om på to foreldremøter, og samtykkeskjema ble sendt ut på epost før undervisningen. 
2 I kategorien «familie» inngikk sykdom og forestående død i nær familie (besteforeldre), skilsmisse, søskenforhold og vanskelige forhold til foreldre. Åtte lapper ble skrevet om denne tematikken.

3 I kategorien «meg selv» skrev konfirmantene elleve lapper. Vennskap, utseende, skolerelatert problematikk som forhold til lærere og lekser, ble nevnt her samt psykiske utfordringer som angst og utenforskap.

\section{RESPONS ETTER UNDERVISNINGEN \\ Hjemmeoppgaven}

Før undervisningen ble avsluttet, fikk konfirmantene informasjon om hjemmeoppgaven om påsken. Instruksjonen var at de skulle ta fire bilder med eget kamera, om det de mente representerte påskens fire viktigste dager, og skrive en kort tekst til hvert bilde. Jeg forklarte at grunnen til denne typen av hjemmeoppgave skulle gi meg et inntrykk av hva de satt igjen med etter undervisningen. Det var mange konfirmanter som tok bilder med eget kamera, og en del som brukte bilder fra internett. Det var kun et fătall som knyttet påskedagene til egen hverdag med skole, venner og fritid, eller til ritualer fra undervisningen, som for eksempel håndvasken på skjærtorsdag. De fleste tok bilder av veldig konkrete ting, som symboliserte de forskjellige påskedagene, og tekstene hadde et hovedsakelig faktaorientert uttrykk. Svarprosenten på hjemmeoppgavene var 90 prosent.

Jeg skal kort sammenfatte bilde- og tekstvalg til de forskjellige dagene nedenfor.

\section{Palmesøndag}

De aller fleste bildene til palmesøndag forestilte palmer, eller palmelignende planter eller trær, slik som tujablader, grantrær eller potteplanter inne i hjemmet. Et bilde av et grantre fikk teksten: «Denne greinen er det nærmeste man kommer palme i Norge.» Hovedtrekkene i tekstene handler om inntoget $\mathrm{i}$ Jerusalem og hvordan palmegreinene, både som folket viftet med og la ned på bakken foran ham, symboliserte håp, glede og lettelse.

\section{Skjærtorsdag}

En klar majoritet av konfirmantene hadde bilder av brød og vin, som symbol for skjærtorsdagen. Det var også bilder av malerier fra det siste måltid. Noen konfirmanter hadde tatt bilder av såpe eller vann. En av konfirmantene hadde tatt flere bilder av vann og beskrev hvordan Jesus vasket disiplenes føtter for å vise at ingen er bedre enn andre og at Gud elsker alle like mye. En annen skrev i bildeteksten at fotvaskingen var et tegn på respekt. Andre hadde tatt bilder av et dekket bord. I tekstene til bildene står det hvordan brød og vin representerer 
nattverden, som er Jesu siste måltid med disiplene. Noen kombinerer beskrivelse av måltidet og fotvaskingen.

\section{Langfredag}

Cirka halvparten av langfredagens bilder forestilte et kors. Enten et kors som de hadde laget av to plankebiter, pinner, tegneseriebøker, eller blader, eller av «vanlige» kors. Noen hadde brukte bilder av Jesus på korset og tre tomme kors i solnedgang. Døde planter og tornekvister forekom, i tillegg til klokker og timeplaner - som symboliserte en lang og tung skoledag. Konfirmantene valgte også bilder av levende lys og en kirkegård. Hovedtrekk i tekstene er at korset representerer hvordan Jesus ble hengt på korset og døde, og at korset er kristendommens viktigste symbol.

\section{Første påskedag}

På første påskedag var bildevalget noe mer variert, selv om det var noen motiver som ble valgt i større grad enn andre. I dette tilfelle var det bilder av blomster i forskjellige varianter. Det var både roser, påskeliljer, hestehov og potteblomster. De skulle symbolisere nytt liv og hvordan det er vanlig å legge blomster på en grav. Bilder av en stein var det også en del konfirmanter som valgte. Den ga konfirmantene assosiasjoner til steinen som var foran Jesu grav, eller steinen som var rullet vekk da Maria Magdalena kom til graven.

\section{INTERVJUER MED ÅTTE INFORMANTER}

Basert på hjemmeoppgavene konfirmantene leverte, valgte jeg ut fire jenter og fire gutter til intervju. Metoden for utvelgelsen handlet om hvordan jeg trodde at de kunne besvare mine forskningsspørsmål: Hvordan responderer konfirmanter på kirkens påskefortelling med underspørsmålet om denne responsen kunne få følger for undervisningens metodikk (Bryman, 2012, s.418). Derfor ville jeg ha lik kjønnsbalanse og variasjon i bilde og tekstmateriale. Noen konfirmanter skrev korte tekster, andre lenger. Bildebruken var også variert. Jeg spurte dem om hva de visste om kristen påske før konfirmasjonsundervisningen, om de hadde lært noe nytt i etterkant av den, og om bilde- og tekstvalg i hjemmeoppgaven. Samtlige åtte informanter sa at de hadde kjennskap til den kristne påsken før konfirmantundervisningen, og de ga uttrykk for at de hadde lært om den på barneskolen. Noen informanter spesifiserte 4.-5 klasse. De kjente til hva som skjedde de fire dagene, men da jeg spurte dem, var de mest konkrete på at Jesus døde på langfredag og sto opp igjen første påskedag. Samtidig var det en informant som ikke kjente til at Jesus døde på langfredag, mens en annen ikke visste hva som skjedde på skjærtorsdag. Alle informanter sa at de hadde lært noe nytt av konfirmantundervisningen, men to av dem kunne ikke si noe spesifikt om 
hva denne nye kunnskapen var. To informanter knyttet undervisningen opp mot kirkelig praksis på gudstjenesten og mot en tidligere konfirmantundervisning $\mathrm{i}$ januar. Den ene informanten hadde vært ministrant på en påskefestgudstjeneste i menigheten, rett før påskeundervisningen, og hadde da lest bibelfortellingen fra skjærtorsdag, og det hadde hun brukt da hun valgte tekst og bilde til hjemmeoppgaven. Den andre brukte nattverden i kirken som representativ for skjærtorsdag, og valgte derfor bort et bilde på vann eller såpe for fotvaskingen. Syv av åtte informanter husket at jeg og presten vasket hendene deres, men kun halvparten satte det i sammenheng med skjærtorsdag. De sa at de husket hendelsen fordi den var uventet, høytidelig og noe de gjorde, i stedet for å sitte og høre på. To informanter sa at håndvasken lærte dem noe om hvordan en skal behandle andre mennesker med respekt. Fem av åtte informanter angir elementer fra den muntlige fortellingen fra skjærtorsdag og første påskedag, som ny kunnskap, mens én angir input teori fra palmesøndagen som ny kunnskap.

Når det gjaldt bilde- og tekstvalg, fikk jeg inntrykk av at de fleste informantene hadde valgt ting de hadde hjemme og i umiddelbar nærhet. Disse konkrete tingene fikk dem til å assosiere til hendelsesforløpet i påsken, som for eksempel visne planter på verandaen, en pynteengel, en brødbit, eller en melkekartong med en lapp hvor det sto «100 \% fornybar» på siden. Det var også informanter som hadde brukt egne bilder fra påskeferie eller fra internett. Jeg forsto noen informanter slik at det var enklest å velge bilder hjemmefra, da de fikk dårlig tid og «måtte» finne på noe. Andre kunne ikke helt begrunne bilde- eller tekstvalg. To av informantene brukte et konkret hendelsesforløp i sine hjemmeoppgaver, hvor den ene angir tydelig interaksjon mellom Jesus og disipler, eller røverne han ble korsfestet med. En av informantene har valgt alle bilder fra internett, men to av disse bildene speiler hva han lærte i undervisningen, både fra input teori og fra håndvasken. Alle informanter sa at de hadde funnet bilder og tekst selv, uten å samsnakke med noen venner fra konfirmantgruppa.

\section{ForHOLDET MELLOM GJENNOMFøRT OG ERFART LEREPLAN}

Var det samsvar mellom gjennomført og erfart læreplan i dette caset, det vil si mellom prestens og min konfirmantundervisning og konfirmantenes respons på denne? For å forklare det mulige samsvaret vil jeg i det følgende trekke inn teori om kontekstuell teologi og kontekstuell religionsdidaktikk.

Utformingen på denne konfirmantundervisningen har vært den samme i tre år, med noen variasjoner. Det viktigste for de ansatte var at konfirmantene skulle kjenne innholdet i de fire viktigste påskedagene gjennom ritualer, visuelle inntrykk og fortelling, i en ramme som kunne oppleves som relevant i deres eget liv. Kirkens påskefortelling ble muntlig fortalt, det ble brukt visuelle hjelpemidler som palmeblader, trekors, blomster og lys. I tillegg ble konfirmantenes hender 
vasket. Den tydeligste tendensen i konfirmantenes respons var at de framhevet den muntlige fortellingen og håndvaskingen. Vi som ansatte i menigheten underviste og fortalte påskefortellingen fra Matteusevangeliet. Denne mente vi var kunnskapsstoff, som vi ville gi videre til konfirmantene. Konfirmantene tok bibeltekstene videre til sin kontekst da de arbeidet med hjemmeoppgavene. Ut fra responsen ble det tydelig at i deres kontekst ble et hva viktigere enn et hvorfor. Man kan dermed si at vi som ansatte ønsket å overføre vår forståelse av påskefortellingen til konfirmantene. Overførbarhet betyr at det finnes grenser, eller forskjellige kontekster, og at kunnskap, som et eget vesen, kan overføres fra kontekst til kontekst (Sfard, 1998, s. 9). Denne kunnskapen repeteres og forandres i forskjellige kontekster, og dette danner et kompetansegrunnlag til forberedelse for morgendagens eventuelle hendelser og situasjoner (Sfard, 1998, s.9). I denne sammenheng kan målformuleringen om å kjenne innholdet i de fire viktigste påskedagene, bidra til å gi konfirmantene en kompetanse til å lese den vestlige verdens kalendere og forstå betydningen av den. Denne tankegangen er også forenlig med praksismodellen i kontekstuell teologi. Den har en sirkulær bevegelse ut fra Guds åpenbaring i historien og i hverdagen, med formål å repetere praksis, reflektere over praksisen og forandre det som må forandres (Bevans, 2002, s. 76).

En av informantene svarte i intervjuet:

Jeg læerte mye om Maria Magdalena på første påskedag, når hun kom til graven og hun så at graven var tom og så kom Jesus, det er også noe jeg husker. Jeg tror vi gikk gjennom det $i$ hvert fall to ganger.

I Tro, livstolkning og tradisjon (1997, s. 219, 223) henvises det til en fortellingsdidaktikk som var en del av det gamle kristendomsfaget på skolen. En fortelling kjennetegnes av at den har en forteller og at det er en distanse i tid mellom fortellersituasjonen og hendelsene. Fortellingen har ord som uttrykker kronologi, først, deretter, etterpå osv. En lærer som behersker fortellerkunsten, kan få elevenes oppmerksomhet, uavhengig av alder. Gjennom den muntlige fortellingen kan elevene få et innblikk i en historie som ble til i en annen tid og kultur, og fortellingsdidaktikken har et fortrinn fremfor forelesing eller høytlesing. Den muntlige fortellingen har bidratt til å gi verden mening for menneskene opp igjennom historien, og den retter seg til en gruppe mennesker, og gir individet fritt rom til egentolkning (Afdal, Haakedal, Leganger-Krogstad; 1997, s. 220-221).

Det ble en egen stemning da vi ansatte fortalte. Vi opplevde å få øyekontakt med konfirmantene, og de fulgte godt med og var fokuserte under fortellingen. Da flere lesespørsmål viser til elementer fra den muntlige fortellingen, i tillegg til hjemmeoppgaver og intervjuer med informantene, heller enn bibelteksten, 
viser det at den muntlige fortellingen kan ha bidratt til å gi påskefortellingene en mening, fremfor den skriftlige versjonen. Dette viser til stort samsvar mellom gjennomført og erfart læreplan. Videre oppdaget vi at påskefortellingen kan være identitetsskapende.

I fortellingsdidaktikken brukes fortellingen som nettopp det. Mennesker bruker en jeg-fortelling, når de skal fortelle om hvem de er. Her inngår både navn, etternavn og hvor de bor, som sier noe om deres hverdag og kontekst. Denne jeg-fortellingen går inn i en vi-fortelling, som både handler om familiens liv og historie, lokalmiljøet, samfunnet og det religiøse. Jeg- og vi-fortellingene tolkes ut fra de religiøse universalfortellingene, både i kontrast til - og i overensstemmelse med - disse (Afdal, Haakedal, Leganger-Krogstad, 1997, s. 222).

I rammer for konfirmasjonstiden angir Gud gir - vi deler (Kirkerådet, 2010, 24), hvordan konfirmantene skal kjenne Bibelens store fortelling, sett i lys av sin egen og fellesskapets fortelling. Det kan være verdt å unders $\emptyset$ ke hva slags fortellinger som preger menighetens kontekst, både som jeg- og vi-fortelling, og plassere påskefortellingen inn i disse, for å $\emptyset$ ke graden av identifisering.

Det ble tidligere nevnt at fortellingsdidaktikken har i seg en egen kronologi. Påskefortellingen ble muntlig fortalt $\mathrm{i}$ tillegg til at den ble lest i bibelen. Konfirmantene gjenga hovedsakelig påskefortellingen i sine hjemmeoppgaver. De brukte kronologi som en måte å organisere den på. I multimodal teori mener Kress (2010, s. 79) at «mode» er et kulturelt gitt redskap for å skape mening. Eksempel på slike redskaper er tale, tekst, gester, bilder og musikk. Disse redskapene kommuniserer på forskjellige måter. Selv om vi brukte forskjellige redskaper i den gjennomførte undervisningen, var intensjonen den samme; å illustrere påskefortellingens forl $\emptyset \mathrm{p}$ fra begynnelse til slutt. Det er dette som konfirmantene responderer på. Multimodale redskaper «oversetter» virkeligheten forskjellig, og da viser et bilde noe annet enn hva ord forteller om virkeligheten (Kress, 2010, s. 96).

I et slikt landskap hvor konfirmanten skal tolke bibelen inn i sin virkelighet, blir det nødvendig med en ny gjennomgang av Goodlad (1979) og hans teori om læreplaner. I doktoravhandlingen Tolerance and curriculum (2005) ser Geir Afdal på hvordan Goodlad's (1979) ansikter forholder seg til hverandre. Afdal mener at ansiktene er autonome og at relasjonene dem imellom er komplekse og kontekstavhengig (Afdal, 2005, s. 81-82). Ifølge Goodlad utvikles en læreplan på samtlige nivåer $\mathrm{i}$ en kontekst, og planlegging og fornyelse kan skje eller starte hvor som helst i prosessen. Det vil si at ansiktene ikke bør ordnes hierarkisk, men heller syklisk, hvor de er i konstant påvirkning og samvirke med nasjonal, lokal og skolens, i denne sammenheng menighetens, kontekst (Afdal, 2005, s. $78,94)$. Det teologiske utgangspunktet for denne undervisningen var kontekstuell teologi og praksismodellen, hvor repetisjon og refleksjon over handling 
skaper forandring. Afdal bruker også Bevans (2002) praksismodell i en pedagogisk hensikt, hvor han sier at læreplanen er en slags handlingsprosess. En læreplan skal motivere til refleksjon og nye handlinger (Afdal, 2005, s. 87). Jeg mener at konfirmantundervisning bør ha som mål å legge til rette for repetisjon og refleksjon over handlinger som kan skape nye handlinger. I dette tilfelle kan det ikke gjøres rede for hvorvidt konfirmantene fikk et nytt handlingsmønster som følge av konfirmantundervisningen, men det responsen peker på, er at de har fătt ny kunnskap og kompetanse om påskens fire viktigste dager. Den kompetansen inneholdt også holdninger som respekt, samhold og likeverd. Det kom fram i bilde- og tekstvalg fra hjemmeoppgaven, spesielt under skjærtorsdag. Bildene som symboliserte likeverd og respekt, var bilder av vann, såpe og vann eller fotvask. Bilder av brød og vin symboliserte hos noen konfirmanter middagsfellesskapet og samhold. To av informantene fortalte under intervjuet at de hadde lært mer om skjærtorsdag og at håndvaskingen var et tegn på respekt.

Den erfarte læreplan som mitt prosjekt har gitt meg innblikk i, har allerede ført til en justert praktisert læreplan for det neste konfirmantkullet. Slik ser en at bevegelsen mellom de ulike ansiktene av en læreplan kan være toveis.

I min analyse av datamaterialet har jeg sett at det kronologiske fortellingsløpet i påskens fire viktigste dager - «det som skjedde», er det viktigste for konfirmantene. Dette kan være et uttrykk for majoritetens tilhørighet til kulturkristendom. De ønsker å inneha nødvendig allmennkunnskap om påskehøytiden. Hvilken betydning påskefortellingen har i deres liv, er sekundært. Vårt frigjøringsteologiske utgangspunkt synes å ha vært feilberegnet på målgruppen. Hvis de konfirmantene vi møtte i vår menighet, var nokså trygge og veltilpassede, med stor tro på framtiden, var de kanskje mindre tilbøyelige til å betrakte verden ut fra et $\emptyset$ nske om å forandre den. De syntes å ha mindre behov for en virkelighetsforståelse som krever personlig endring og forpliktelse på et budskap om frigjøring, enn $\emptyset$ nske om å beholde sin «lokale» verden som den er. I den store verden så de likevel et behov for frigjøring og forbedring.

\section{KonkLuSJON}

Hvilke følger får konfirmantenes respons for undervisningens metoder? Konklusjonen er at det bør legges didaktisk til rette for at påskefortellingens virkelighet samsvarer med konfirmantenes virkelighet. Da blir den første metoden fortellingsdidaktisk hvor de ansatte lærer bibelfortellingen, eller en bearbeidet versjon, utenat og forteller den til konfirmantene. Responsen viser at den muntlige fortellingen ikke skaper samme distanse som den skrevne bibelteksten. Den andre metoden er å skildre påskefortellingen som en uventet, fellesskapsbyggende handling. Her var håndvaskingen et effektivt pedagogisk verktøy. Både håndvaskingen og inputteorien om nattverdsmåltidet satte flere konfirmanter i 
sammenheng med holdninger som respekt, samhold og likeverd. Den tredje og siste metoden for å kommunisere påskefortellingens virkelighet er da påskefortellingen presenteres som en faktisk virkelighet. Her vektlegger jeg spesielt langfredagsteksten, hvor Jesu lidelse og død på korset ble kommunisert med hvordan kristne i hele verden finner trøst i tro på en Gud som vet hva lidelse og urettferdighet er. Bønnelappene som konfirmantene skrev, viser at denne formidlingen av bibelteksten samsvarte med deres virkelighet og ga den mening, da de selv ga uttrykk for urettferdighet og lidelse, på forskjellige måter, ut fra egne erfaringer.

\section{LITTERATUR}

Afdal, Geir (2005): Tolerance and curriculum - conceptions of tolerance in the multicultural unitary Norwegian compulsory school, Det teologiske Menighetsfakultet, Oslo

Afdal Geir, Haakedal Elisabet, Leganger-Krogstad Heid (1997): Tro, livstolkning og tradisjon. Innføring i kontekstuell religionsdidaktikk, Universitetsforlaget, Oslo

Bevans, Stephen B (2002): Models of contextual theology, Orbis Books, New York 8 oppl Bryman, Alan (2012): Social research methods, Oxford university press, Oxford $4 \mathrm{oppl}$

Goodlad, John I. mfl (1979): Curriculum Inquiry. The study of Curriculum Practice, N.Y. MacGraw-Hill

Gundem, Bjørg Brandtzæg (1990): Lœreplanpraksis og læreplanteori. En innføring, Universitetsforlaget, Oslo

Imsen, Gunn (2009): Lœrerensverden - Innføring igenerell didaktikk, Universitetsforlaget, Oslo

Kirkerådet, Den norske kirke (1998): Plan for konfirmasjonstiden i Den norske kirke

Kirkerådet, Den norske kirke (2010): Plan for trosopplcering Gud gir - vi deler

Konfirmantbibelen (2012) Bibelselskapet

Kress, Gunther (2010): Multimodality - a social semiotic approach to contemporary communication, Routledge, New York

Skeie, Eivind (1997): Peters påske, IKO-Forlaget, Oslo

Vesterberg, Caroline Anna (2017): Hvordan responderer konfirmanter på kirkens påskefortelling? - En kvalitativ studie av en konfirmasjonsundervisning med vekt på hvilke følger konfirmantenes respons kan ha for undervisningens innhold og metoder, Det teologiske menighetsfakultet 


\section{Vedlegg: Bilder fra informantene}

Jeg har valgt ut et bilde til hver av dagene, fra fire av de åtte informantene som ble intervjuet.

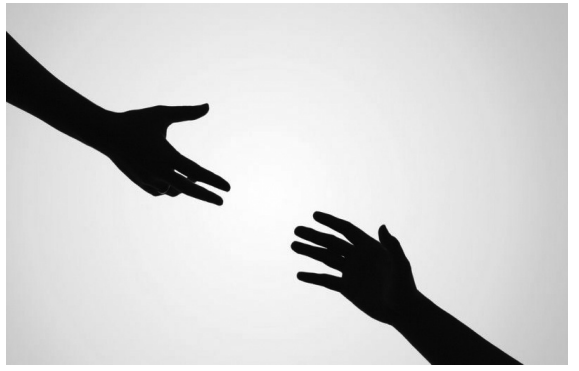

\section{Palmesøndag:}

Da Jesus kom inn $i$ byen ridende på et esel, ble folk veldig glade. De trodde Jesus skulle vare kongen deres og skulle starte krig. De trodde han skulle hjelpe dem på den måten.

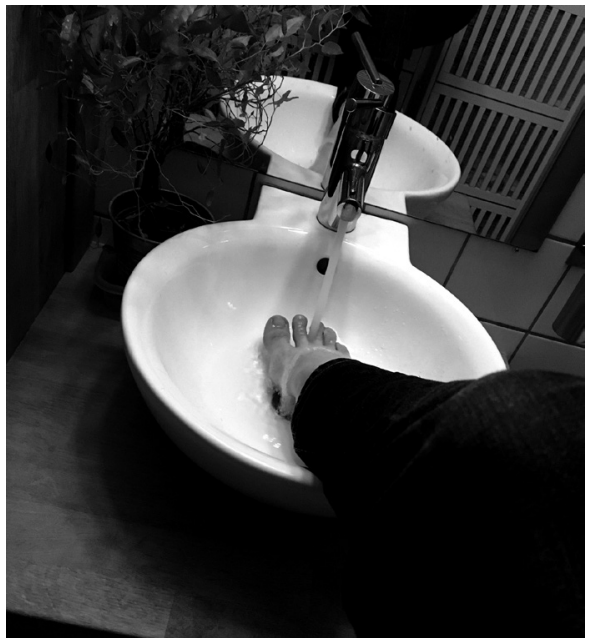

\section{Skjærtorsdag:}

Jesus vasker føttene til disiplene sine. Dette er et tegn på respekt og disiplene til Jesus lurer på hvorfor han gjør det.

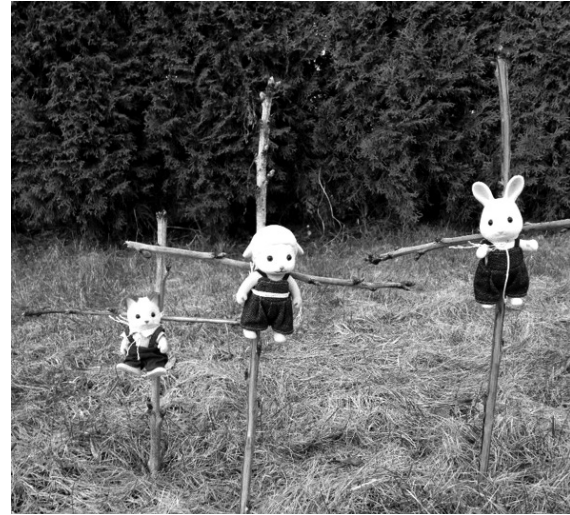

\section{Langfredag:}

Langfredag feirer vi til minne om Jesu $d ø d$. Da han ble hengt på korset.

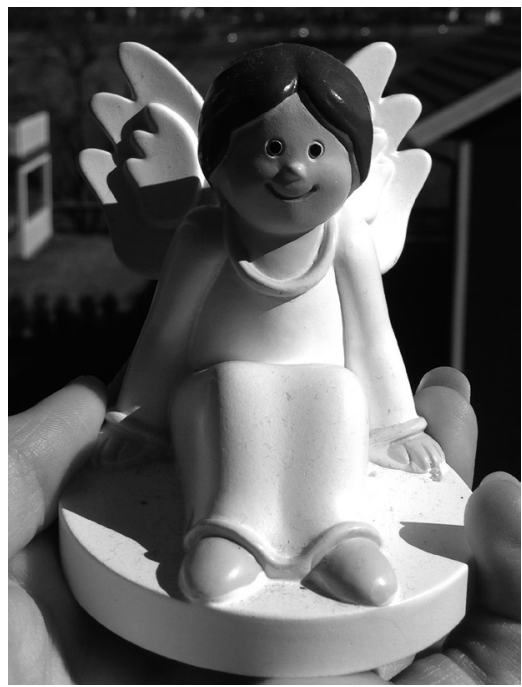

Påskedag:

Da kvinnene kom til den tomme graven til Jesus på påskedag, var det en engel som satt der. 